\title{
Activated and inactivated immune responses in Caenorhabditis elegans against Photorhabdus luminescens TT01
}

Kazuki Sato ${ }^{1,2,3}$, Toyoshi Yoshiga ${ }^{1,2}$ and Koichi Hasegawa ${ }^{4^{*}}$

\begin{abstract}
The Gram-negative bacterium Photorhabdus luminescens which symbiotically associates with the entomopathogenic nematode Heterorhabditis bacteriophora, has a broad insecticidal and nematicidal activity. The virulence of $P$. luminescens toward the non-mutualistic nematode Caenorhabditis elegans has not been described. We showed that when fed on P. luminescens, the intestinal cells of C. elegans worms become delicate and some crystal-like structure was developed within the intestinal lumen. Next, we examined the requirement of the p38 mitogen-activated protein kinase (MAPK) and insulin/IGF-1 signaling pathway against $P$. luminescens. Depletion of pmk-1 by RNAi enhances susceptibility to P. luminescens, and numerous downstream targets regulated by the P38 MAPK pathway were induced when fed on $P$. luminescens. On the other hand, knockdown of daf-16 has no effects on C. elegans lifespan, but knockdown of daf-2 dramatically increased resistance to $P$. luminescens in a daf-16-dependent manner. We also revealed one of the daf-2 ligands ins-7 was induced and ins-7 deletion mutant survived longer when fed on $P$. luminescens. These results suggest the p38 MAPK pathway is activated and required for the host defense against $P$. luminescens. Insulin/IGF-1 signaling pathway is inactivated by $P$. luminescens through the overexpression of insulin-like gene.
\end{abstract}

Keywords: Entomopathogenic nematode; Photorhabdus luminescens; Caenorhabditis elegans; Insulin/IGF-1; Heterorhabditis bacteriophora; Pathogenicity

\section{Background}

Photorhabdus luminescens is an enteric Gram-negative bacterium which can be a pathogen producing a broadspectrum toxins with antibacterial, antifungal insecticidal, and nematicidal activities, or a symbiont of the entomopathogenic nematode (EPN) Heterorhabditis bacteriophora orchestrating insect pathogenicity (Waterfield et al. 2009). A highly specialized mechanism of the bacteriumEPN association and adaptation has evolved and well established. Infective juveniles (IJs) of the EPNs invade the insect hosts and release their symbiotic bacteria into the hemocoel (Ciche and Ensign 2003). The bacteria suppress insect host defenses via production of phenoloxidase inhibitor (Eleftherianos et al. 2007), and produce insecticidal toxins to kill insect hosts within 48 hours after infection. EPNs consume bacteria and insect tissues to support their

\footnotetext{
*Correspondence: koichihasegawa@isc.chubu.ac.jp

${ }^{4}$ Department of Environmental Biology, College of Bioscience \&

Biotechnology, Chubu University, 1200 Matsumoto, Kasugai 487-8501, Japan Full list of author information is available at the end of the article
}

growth and reproduction. Meanwhile, the bacteria produce antibiotics and deterrent chemicals to protect the insect cadaver from microorganisms and other scavenger animals (Richardson et al. 1988; Williams et al. 2005; Gulcu et al. 2012). IJs emerge under the control of $H$. bacteriophora-producing pheromone (Noguez et al. 2012), are released from the insect cadaver carrying their aggressive symbiotic bacteria in the intestine and seek for new hosts (Ciche 2007).

Several toxin proteins produced by $P$. luminescens and other pathogenic bacteria have been identified, e.g. the toxin complex (Tc), the "Makes caterpillars floppy" (Mcf), Photox, and Photorhabdus insect related (Pir) toxins (Bowen et al. 1998; Daborn et al. 2002; Duchaud et al. 2003; Visschedyk et al. 2010). Even though the pathogenicity of several $P$. luminescens toxins is under active investigation (Dowling et al. 2004, 2007; ffrenchConstant et al. 2007; Vlisidou et al. 2009; Lang et al. 2010, 2011, 2013; Gatsogiannis et al. 2013; Yang and Waterfield 2013) and the genome data of $P$. luminescens 
are available (Duchaud et al. 2003), the underlying mechanism of their virulence remains unclear.

The mechanisms of host defense response against bacterial pathogens have been recently studied using the genetic model organism Caenorhabditis elegans. This approach successfully identifies the broadly conserved pathways involved in the host responses, e.g. Toll-like receptor pathway (Pujol et al. 2001; Tenor and Aballay 2008), p38 MAPK pathway (Kim et al. 2002; Troemel et al. 2006; Shivers et al. 2009, 2010), insulin/IGF-1 signaling pathway (Garsin et al. 2003; Murphy et al. 2003; Kawli and Tan 2008), and SKN-1/NRF oxidative stress pathway (van der Hoeven et al. 2011; Papp et al. 2012).

Although several studies have indicated that some $P$. luminescens strains displayed pathogenicity toward $C$. elegans (Couillault and Ewbank 2002; Sicard et al. 2007; Engelmann et al. 2011; Fischer et al. 2012, 2013; JulienGau et al. 2014), detailed phenotypes and the roles of host defenses have not been characterized. In this study we tested the pathogenicity of $P$. luminescens TT01, a mutualistic bacterial strain of the H. bacteriophora TT01 to $C$. elegans. Here we reported the phenotypes observed in C. elegans when infected by $P$. luminescens and revealed a similar molecular strategy with other pathogens to exert its pathogenicity.

\section{Results}

P. luminescens TT01 causes drastic damage to C. elegans intestine

C. elegans can be infected by many other bacterial strains (Couillault and Ewbank 2002; Sicard et al. 2007; Engelmann et al. 2011; Fischer et al. 2012, 2013; Julien-Gau et al. 2014). Here we showed that $P$. luminescens TT01 was also highly pathogenic to C. elegans. More than $90 \%$ of L4staged C. elegans feeding on P. luminescens died within 5 days (Figure 1, Table 1, Blank RNAi). Body and brood size were largely reduced and the hatched larvae are developmentally retarded; most of the F1 did not develop to adulthood (data not shown). C. elegans intestinal cells were delicate. After 2 hours of feeding, the intestinal lumen started to swell and some crystal-like structures began to form (Figure 2A-D). This layered crystal-like structure was also observed in another bacteriovorous nematode Rhabditidae sp. (Additional file 1). Next we cultured L4 stage C. elegans on P. luminescens-seeded plates for 12 hours followed by recovery on Escherichia coli OP50. After 24 and 48 hour feeding on E. coli OP50, the crystal-like structure remained in the intestinal lumen (Table 2) and didn't change the crystal size (Additional file 2), but the body morphology seemed healthy (Additional file 2) and reproduced normally (data not shown).
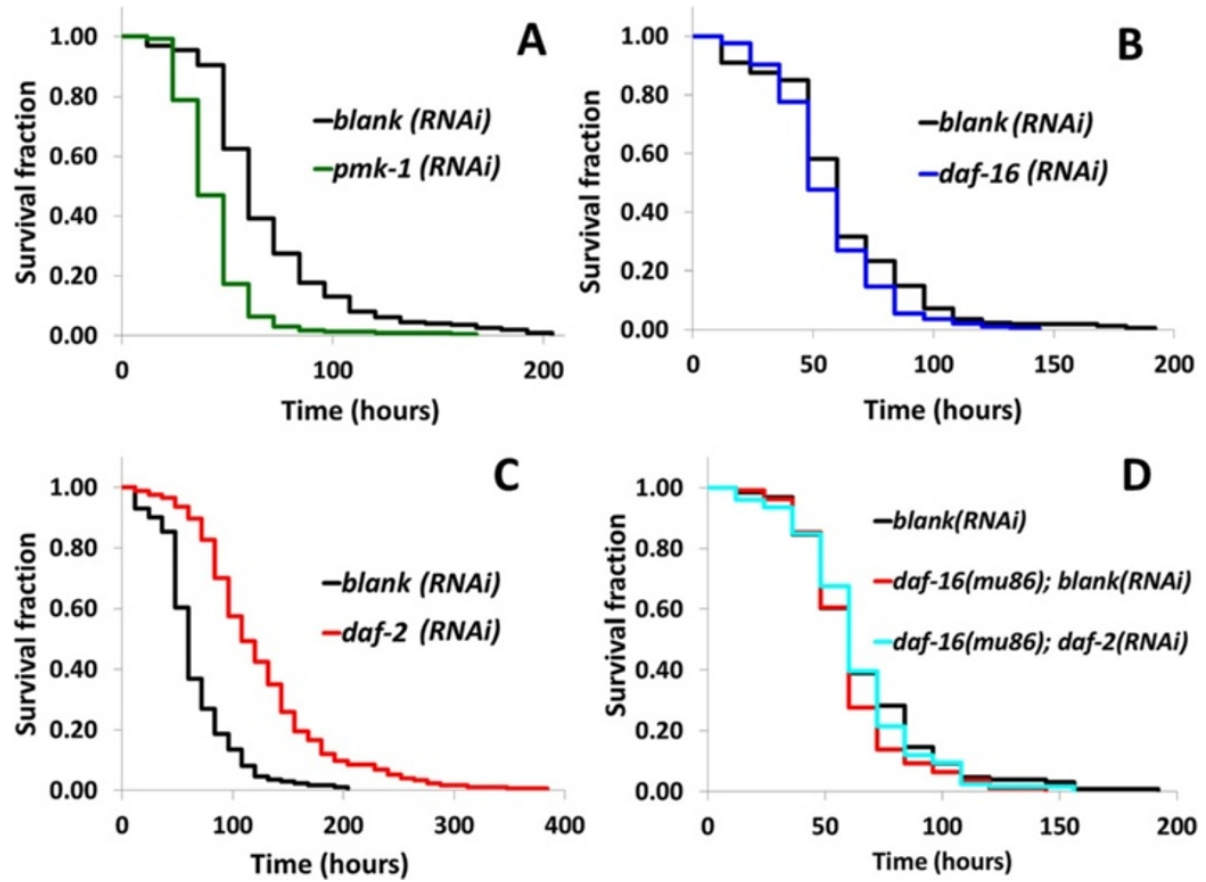

Figure 1 Two pathways contribute to $C$. elegans resistance against $P$. luminescens. (A) pmk-1-knocked down $C$. elegans decreased resistance against $P$. luminescens $(P<0.005)$. (B) daf-16-knocked down did not affect $C$. elegans resistance against $P$. luminescens $(P>0.05)$. (C) daf-2-knocked down $C$. elegans increased resistance against $P$. luminescens $(P<0.005)$. (D) Null mutation of daf-16 did not affect $C$. elegans lifespan $(P>0.05)$, and knockdown of daf-2 didn't affect daf-16 null mutant $(P>0.05)$. Survival curves are presented based on three or two trials (see Table 1$)$. $P$ values were calculated by log-rank test compared with the blank(RNAi). 
Table 1 Effect of $P$. luminescens on $C$. elegans lifespan

\begin{tabular}{|c|c|c|c|c|c|}
\hline Trial & Genotype & Lifespan* & $\%$ increase & $\mathbf{n}$ & $P$ value $* *$ \\
\hline \multirow[t]{4}{*}{1} & N2, Blank(RNAi) & 63.7 & & 39 & \\
\hline & N2, pmk-1(RNAi) & 42.4 & -33.4 & 73 & $<0.005$ \\
\hline & N2, daf-16(RNAi) & 55.9 & -12.2 & 47 & $>0.05$ \\
\hline & $\mathrm{N} 2$, daf-2(RNAi) & 140.0 & +119.8 & 42 & $<0.005$ \\
\hline \multirow[t]{3}{*}{2} & $\mathrm{~N} 2$, Blank(RNAi) & 65.3 & & 77 & \\
\hline & N2, pmk-1(RNAi) & 48.5 & -25.8 & 79 & $<0.005$ \\
\hline & N2, daf-16(RNAi) & 55.6 & -14.8 & 71 & $>0.05$ \\
\hline \multirow[t]{3}{*}{3} & N2, Blank(RNAi) & 75.0 & & 81 & \\
\hline & N2, pmk-1(RNAi) & 38.6 & -48.5 & 84 & $<0.005$ \\
\hline & $\mathrm{N} 2$, daf-2(RNAi) & 125.3 & +67.1 & 51 & $<0.005$ \\
\hline \multirow[t]{3}{*}{4} & $\mathrm{~N} 2$, Blank(RNAi) & 53.9 & & 51 & \\
\hline & N2, daf-16(RNAi) & 56.7 & +5.2 & 79 & $>0.05$ \\
\hline & $\mathrm{N} 2$, daf-2(RNAi) & 117.4 & +118.0 & 75 & $<0.005$ \\
\hline \multirow[t]{3}{*}{5} & $\mathrm{~N} 2$, Blank(RNAi) & 62.1 & & 63 & \\
\hline & daf-16(mu86), Blank(RNAi) & 57.5 & -7.3 & 39 & $>0.05$ \\
\hline & daf-16(mu86), daf-2(RNAi) & 65.4 & +5.3 & 58 & $>0.05$ \\
\hline \multirow[t]{3}{*}{6} & N2, Blank(RNAi) & 72.7 & & 68 & \\
\hline & daf-16(mu86), Blank(RNAi) & 62.1 & -14.6 & 70 & $>0.05$ \\
\hline & daf-16(mu86), daf-2(RNAi) & 62.5 & -14.1 & 68 & $>0.05$ \\
\hline \multirow[t]{2}{*}{7} & N2 & 64.6 & & 87 & \\
\hline & ins-7(tm1907) & 76.3 & +18.3 & 83 & $<0.01$ \\
\hline \multirow[t]{2}{*}{8} & $\mathrm{~N} 2$ & 64.0 & & 88 & \\
\hline & ins-7(tm1907) & 77.1 & +20.6 & 75 & $<0.05$ \\
\hline
\end{tabular}

*Mean lifespan (hour).

**P values of each trial were calculated by log rank test compared with controls.

C. elegans ground E. coli in the terminal bulb, digested them and absorbed the nutrition in the intestinal cells (Figure 3A-D). However, C. elegans couldn't grind the $P$. luminescens, intact bacterial cells remained but the bacteria did not proliferate in the intestinal lumen (Figure 3E-H).

\section{Two pathways influence $C$. elegans resistance to}

\section{$P$. luminescens}

Given that the insulin/IGF-1 signaling pathway and the p38 MAPK pathway in C. elegans are required for the defense response against several bacterial infections in intestine (Tan and Shapira 2011), we examined the role of these pathways against $P$. luminescens. The bZIP transcription factor ATF-7 is phosphorylated by the MAP kinase PMK-1 (Shivers et al. 2010), which activates numerous antimicrobial enzymes and peptides such as LYS-2 and CLEC-67 (Troemel et al. 2006). When the pmk-1 was knocked down by RNAi, C. elegans lifespan decreased significantly $(P<0.005)$ (Figure $1 \mathrm{~A}$, Table 1 ). The FOXO transcription factor DAF-16 is negatively regulated under the control of the insulin/IGF-1 receptor DAF-2 (Murphy et al. 2003), regulating the expression of antimicrobial enzymes and peptides such as SPP-1, LYS-7 and THN-2 (Murphy et al. 2003; Evans et al. 2008). Knockdown and null mutation of daf-16 did not affect $C$. elegans lifespan $(P>0.05)$ (Figure $1 \mathrm{~B}, \mathrm{D}$, Table 1$)$. On the other hand, $C$. elegans lifespan significantly increased when $d a f-2$ was knocked down $(P<0.005)$ (Figure $1 C$, Table 1). Moreover, knockdown of daf-2 didn't extend lifespan in daf-16 null mutant (Figure 1D, Table 1). The size of crystal-like structure was not affected by these pathways (data not shown).

\section{P. luminescens suppresses some daf-16-regulated antimicrobial genes in $C$. elegans}

Next, we tested the expression of seven enzymes and peptides which are thought to work against microbial infection under the controls of these insulin/IGF-1 and p38 MAPK pathways after 6,12 or 24 hours of P. luminescens exposure. We found that all four p38 MAPKregulated genes, F08G5.6, T24B8.5, lys-2, and clec-67, were induced in each time point (Figure 4). The insulin/ IGF-1-regulated genes, however, were differentially expressed. lys-7 was induced and spp-1 was suppressed in all time points; thn- 2 was induced at 6 hours, unchanged at 12 hours, then repressed at 24 hours (Figure 4). The expression of one of the insulin/IGF-1 peptides, INS-7, 


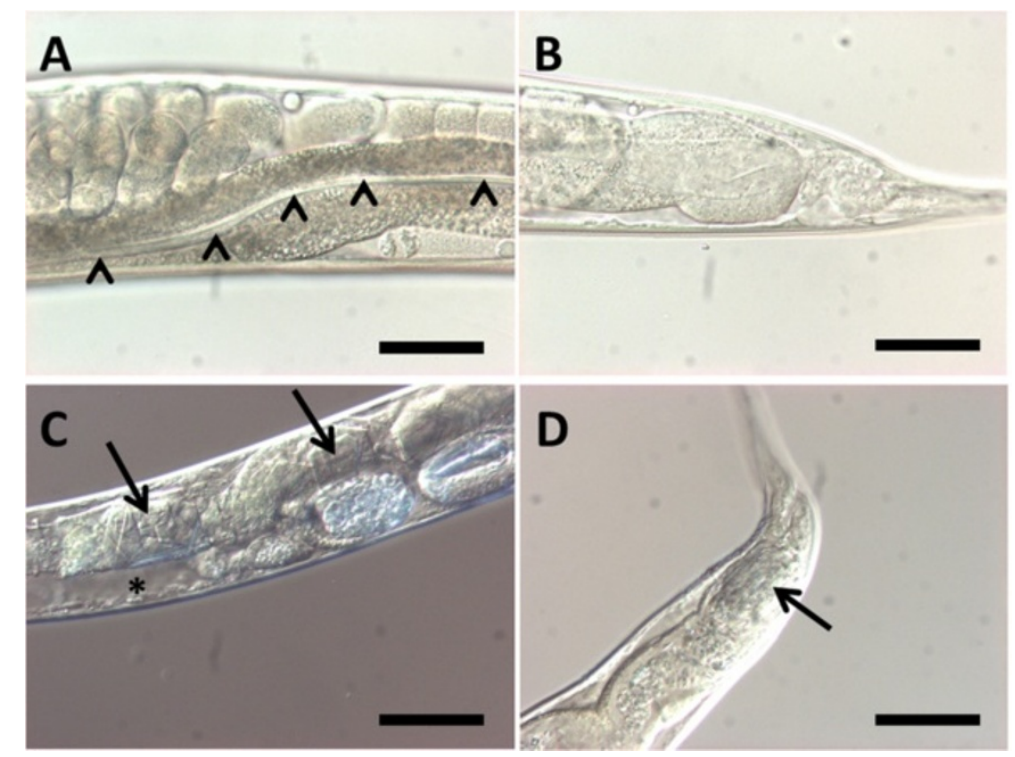

Figure 2 P. luminescens affects C. elegans intestinal cells. (A) Nomarski DIC images of C. elegans intestine fed on E. coli (A, B) or P. luminescens (C, D) for 44 hours. (A) Uterus region. Arrowheads indicate healthy intestinal lumen. (B) Tail region. (C) Uterus region. Intestinal cells are delicate and pseudocoelomic space becomes larger (asterisk). Arrows indicate crystal-like structures constructed in the intestinal lumen. (D) Tail region. Arrow indicates crystal-like structures constructed in the intestinal lumen. Anterior is left. Scale bars, $50 \mu \mathrm{m}$.

a ligand of DAF-2 which suppresses DAF-16 activity (Murphy et al. 2003; Kawli and Tan 2008), was induced at all time points (Figure 4).

Several external stresses, such as starvation, heat, and oxidative stresses induce DAF-16 translocation from cytosol to nucleus, inducing several stress responsive and antimicrobial peptides (Henderson and Johnson 2001). Depletion of daf-16 clearly diminished cytosolic DAF-16::GFP (Figure 5A-D). When daf-2 was knocked down, DAF-16::GFP was accumulated into nuclei (Figure 5E, F). Exposure to P. luminescens TT01 fails to promote DAF-16::GFP translocation (Figure 5G, H).

\section{$P$. luminescens partially suppresses $C$. elegans resistance by INS-7 induction}

Some daf-16-regulated antimicrobial genes were suppressed, and one of the daf-2 ligand ins-7 was induced

Table 2 Crystal-like structures do not disappear once constructed

\begin{tabular}{lcccccc}
\hline & \multicolumn{2}{c}{$\mathbf{P I} \mathbf{1 2} \mathbf{h}+$ Ec $\mathbf{~} \mathbf{h}$} & & \multicolumn{2}{c}{$\mathbf{P I} \mathbf{1 2} \mathbf{h}+$ Ec $\mathbf{4 8} \mathbf{~ h}$} \\
\cline { 2 - 3 } & Crystal & No crystal & & Crystal & No crystal \\
\hline 1st Trial & 10 & 0 & & 20 & 0 \\
\hline 2nd Trial & 18 & 3 & & 18 & 2 \\
\hline 3rd Trial & 20 & 0 & & 18 & 2 \\
\hline
\end{tabular}

Values indicate the number of nematodes in which the crystal-like structure was formed. PI $12 \mathrm{~h}+\mathrm{Ec} 0 \mathrm{~h} ; \mathrm{C}$. elegans grown on $\mathrm{P}$. luminescens for 12 hours from the L4 stage. PI $12 \mathrm{~h}+\mathrm{Ec} 48 \mathrm{~h}$; C. elegans grown on E. coli for 48 hours after 12 -hour incubation on $P$. luminescens from the $L 4$ stage. The significant differences of present/absent of the crystal in each trial were calculated by Fischer's exact test. by $P$. luminescens, given that $P$. luminescens may suppress $C$. elegans resistance by ins-7 inductions. We next examined if the loss of ins-7 function would not suppress $C$. elegans resistance and extend life span. The deletion ins-7(tm1907) mutant significantly increased lifespan (Figure 6, Table 1), suggesting that P. luminescens partially suppresses $C$. elegans resistance by INS-7 induction.

\section{Discussion}

We showed that when C. elegans was fed on P. luminescens TT01, intestinal cells became delicate and eventually collapsed (Figure 2C-D). Some insecticidal toxins such as Tc and Mcf produced by P. luminescens W14 were reported to cause destructions of midgut epithelium in insects (Bowen et al. 1998; Daborn et al. 2002). When $C$. elegans was fed on the recombinant E. coli expressing the $P$. asymbiotica $m c f 1$ gene, severe feeding delay was observed (Waterfield et al. 2008) suggesting the possibility of damage on nematodes intestine. And a toxin complex TcaA was necessary but not sufficient for C. elegans-killing ability in Yersinia enterocolitica (Spanier et al. 2010). Such possible toxins produced by $P$. luminescens might be responsible for the intestinal cell deformation.

To our knowledge, there is no report about the formation of crystal-like structure in nematode intestinal lumen followed by bacterial infection including other Photorhabdus strains. P. luminescens is reported to produce two types of intracellular protein inclusions, CipA 

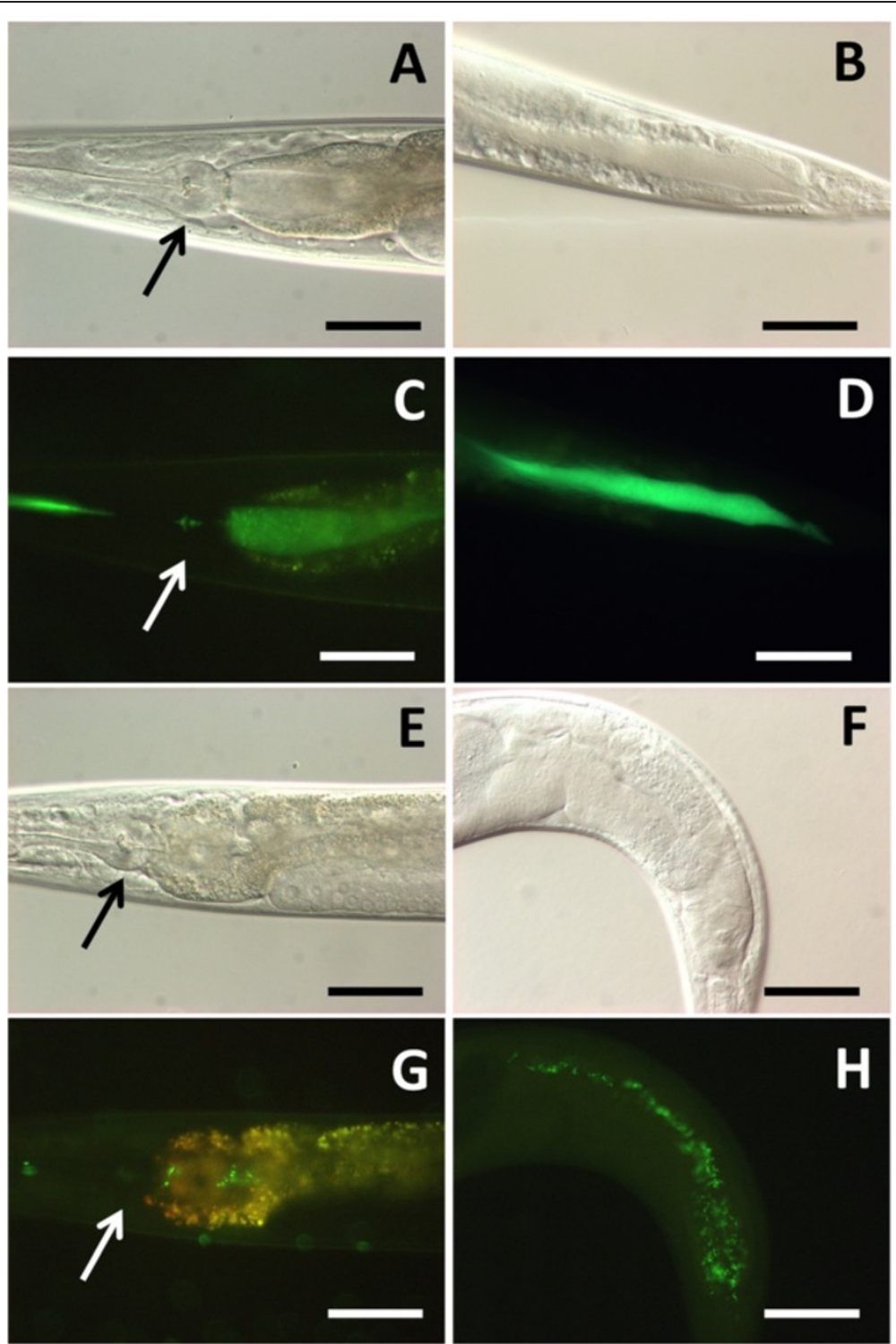

Figure 3 Intact $P$. luminescens gets to the $C$. elegans intestinal lumen. Nomarski DIC (A, B, E, F) or fluorescence (C, D, G, H) images of C. elegans, fed on GFP-labeled E. coli (A-D) or GFP-labeled P. luminescens (E-H) for 24 hours. Intestinal lumen was filled with ground cells when cultured on E. coli (A-D). Intestinal lumen had intact cells when nematodes were cultured on P. luminescens (E-H). Arrows indicate the terminal bulb. Anterior is left. Scale bars, $50 \mu \mathrm{m}$.

and CipB, which support growth and reproduction of the mutualistic EPN but have no effect on insect pathogenesis (Bintrim and Ensign 1998). Because Cip proteins are so small in size and produced inside of the bacterial cell, these inclusion proteins might be different from the crystal-like structure in the present study. The crystallike structure still remains in C. elegans intestinal lumen after transferred onto $E$. coli lawn and their growth and reproduction are resumed (Additional file 2, Table 2); this crystal was unlikely to be toxic for C. elegans.

Many pathogenic bacteria colonize and proliferate in the intestinal lumen of $C$. elegans to exert their pathogenicity (Tan et al. 1999; Garsin et al. 2001; Kurz et al. 2003). Our result clearly showed that $P$. luminescens was not ground up by $C$. elegans terminal bulb, and remained intact into the intestinal lumen without proliferation. This may suggest that $P$. luminescens adopts a different strategy to kill nematodes, for example, via production of toxins without colonization.

Four antimicrobial genes (F08G5.6, T24B8.5, lys-2, clec-67) under the control of the p38 MAPK pathway, were up-regulated when fed on P. luminescens for 6,12 and 24 hours (Figure 4). Up-regulation of these genes was also observed when infected by other pathogenic 

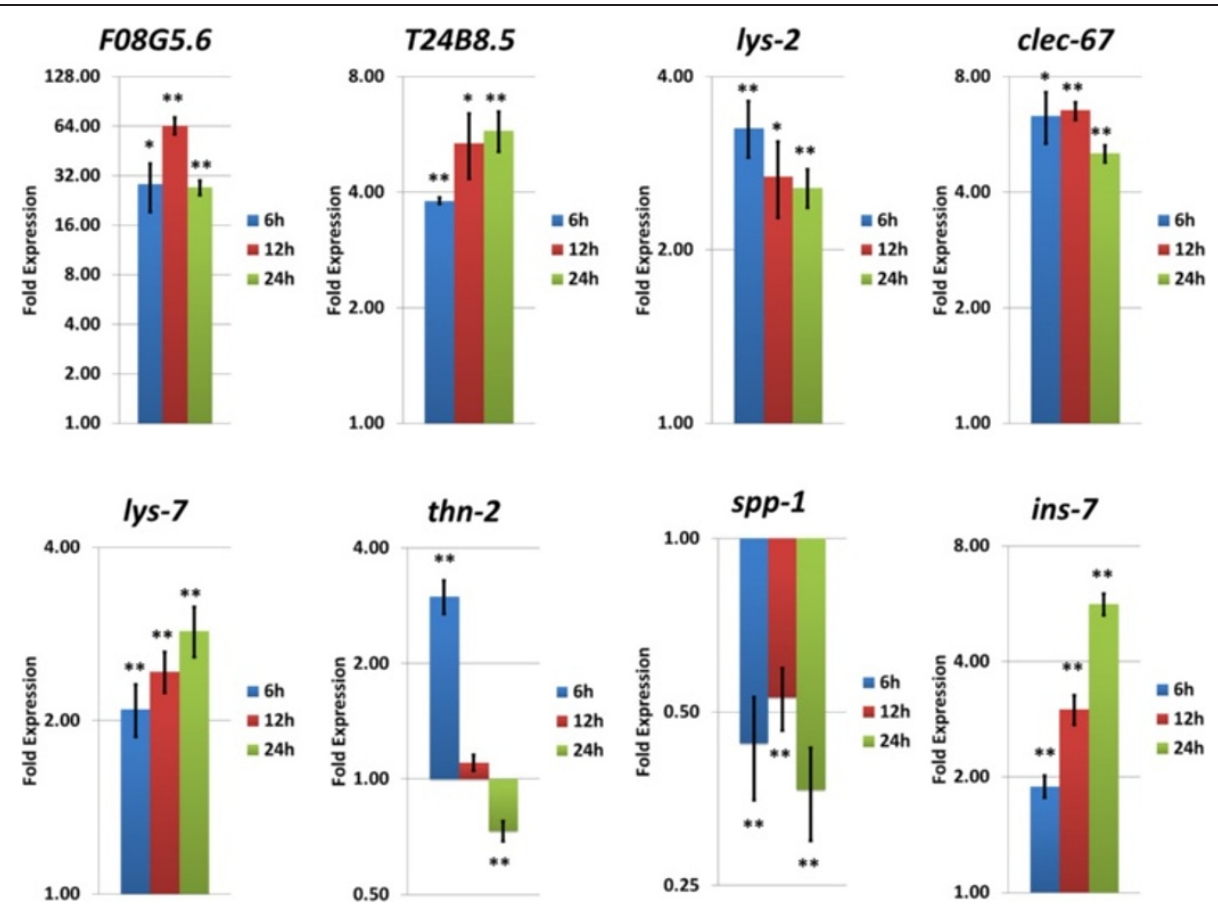

Figure 4 Relative gene expression changes of the seven antimicrobial enzymes and peptides, and ins-7 genes in C. elegans, fed on $P$. luminescens for $\mathbf{6}, \mathbf{1 2}$ and $\mathbf{2 4}$ hours. Values are means \pm SE from at least three independent experiments. The significant differences were determined by Student's t-test, compared to a normalized value of 1.0 for control C. elegans fed on E. coli OP50. ${ }^{*} P<0.05$; ${ }^{* *} P<0.005$.

bacteria e.g. Gram-negative bacterium Pseudomonas aeruginosa (Troemel et al. 2006; Evans et al. 2008; Shivers et al. 2010). In addition, when pmk-1 was knocked down by RNAi, C. elegans became more susceptible to P. luminescens (Figure 1A, Table 1), which suggests that this pathway contributed resistance against $P$. luminescens but didn't affect enough for survival. This pathway is reported to act in a cell-autonomous manner in intestine to regulate innate immunities against bacterial infections (Kim et al. 2002; Troemel et al. 2006; Shivers et al. 2009, 2010; Engelmann et al. 2011).

On the other hand, three antimicrobial genes (spp-1, thn-2, lys-7) regulated by the insulin/IGF-1 signaling pathway showed different expression patterns when fed on P. luminescens (Figure 4). This pathway is also related to host defense against several pathogens (Garsin et al. 2003; Murphy et al. 2003), and its activation is regulated in a non-cell-autonomous manner by secretion of INS-7 from the nervous system, which negatively regulates infection-related genes expression via the transcription factor DAF-16 (Kawli and Tan 2008; Tan and Shapira 2011). Infection of $P$. aeruginosa PA14 suppressed the expression of these three genes through the induction of INS-7 expression (Evans et al. 2008). However, transcriptional analysis using tiling arrays and RNA-sequencing showed the spp-1 and thn-2 were down-regulated, but lys-7 and ins-7 were not affected when C. elegans was fed on P. luminescens strain Hb (Engelmann et al. 2011).

We couldn't observe translocation of DAF-16::GFP into cell nuclei after P. luminescens infection (Figure 5). As shown in our experiments, resistance of $C$. elegans against $P$. luminescens was increased when DAF-16 was activated by daf-2 RNAi (Figure 1C-D, Table 1). However, DAF-16 was not activated by the bacteria, which is consistent with the fact that daf-16 RNAi did not significantly decrease $C$. elegans lifespan on $P$. luminescens (Figure 1B, Table 1).

Up-regulation of ins-7 and the importance of ins-7 for DAF-16 nuclear delocalization during the infection of $P$. aeruginosa to C. elegans have been reported (Evans et al. 2008). P. luminescens induced overexpression of INS-7 in C. elegans (Figure 3), which might keep DAF-16 in the cytoplasm via the insulin/IGF-1 signaling pathway. This mechanism seems unique to $P$. luminescens and $P$. aeruginosa. Gram-positive bacterial pathogen Enterococcus faecalis V583 induces the DAF-16-controlling genes in C. elegans (Evans et al. 2008), and Gramnegative bacterium Salmonella typhimurium induces spp-1 in C. elegans, which contribute to suppress bacterial proliferation in the intestine (Alegado and Tan 2008). Although $P$. luminescens and $P$. aeruginosa suppress the nematode immune response in the same way, they don't 


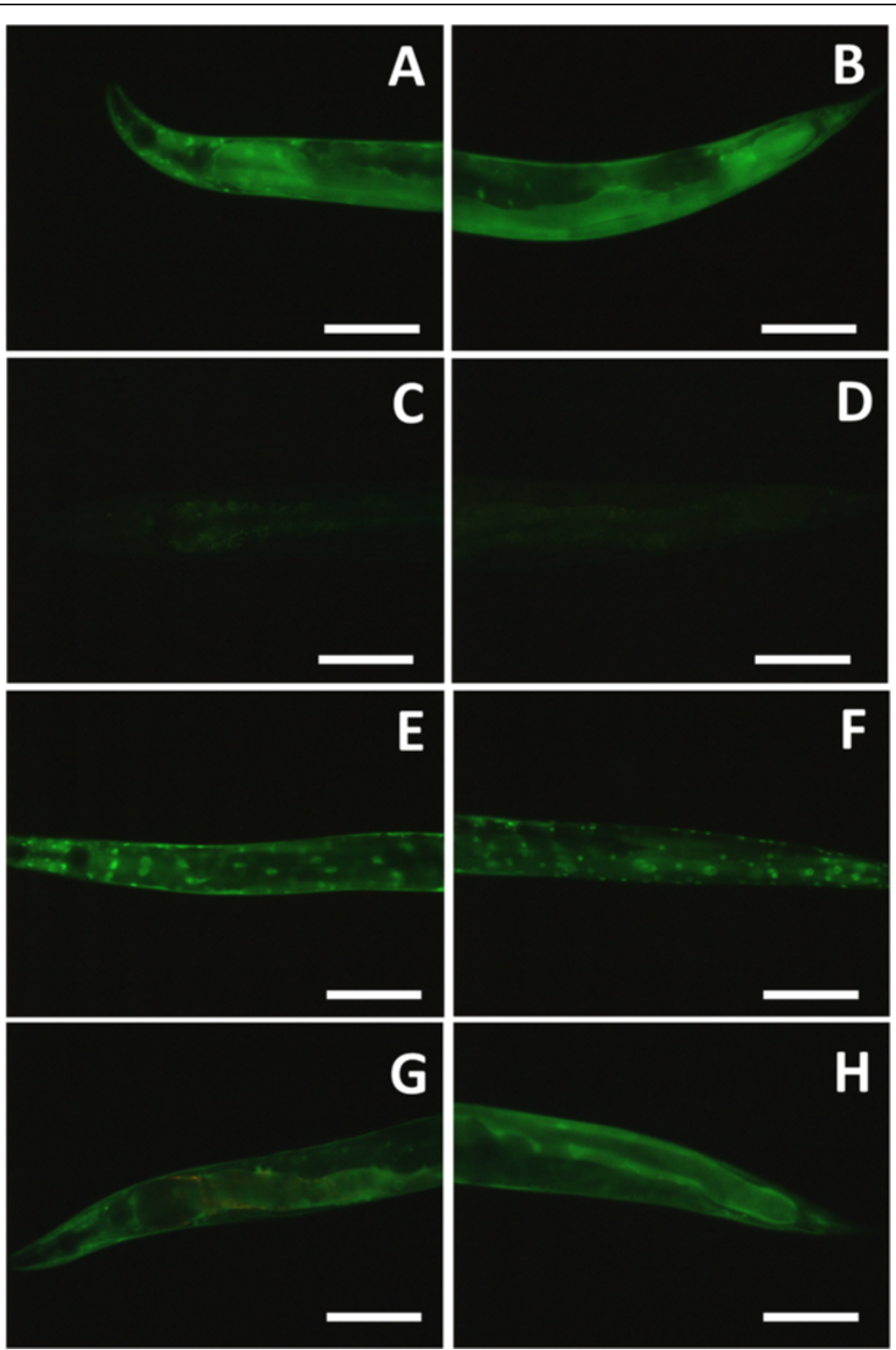

Figure 5 DAF-16::GFP does not respond to P. luminescens. (A, B) DAF-16::GFP was located in cytosol when C. elegans was grown on E. coli OP50. (C, D) Cytosolic DAF-16::GFP was diminished when daf-16 was knocked down. (E, F) Cytosolic DAF-16::GFP was accumulated into the cell nuclei when daf-2 was knocked down. (G, H) DAF-16::GFP translocation was not seen when C. elegans was exposed to P. luminescens $T$ T01. Scale bars, $100 \mu \mathrm{m}$.

share their natural hosts. They might have developed the immune-suppressive mechanism independently.

\section{Conclusions}

We showed here the high pathogenicity of the EPN mutualistic bacterium $P$. luminescens TT01 to the model organism C. elegans. The insulin/IGF-1 signaling pathway is highly effective for the resistance against $P$. luminescens, albeit DAF-16 is inactivated by the bacteria via INS-7 induction, which was also reported in human opportunistic pathogen Pseudomonas aeruginosa PA14.
This infection strategy of P. luminescens might also be applied to infect insects.

\section{Methods}

Nematodes and bacteria strains and culturing

C. elegans and Rhabditidae sp. culturing and handling were performed as described previously (Brenner 1974), except when otherwise noted. Strains used in this study were: Caenorhabditis elegans N2 (Bristol strain), TJ356 \{zIs356[Pdaf-16::daf-16::gfp, pRF4]IV\} (Henderson and Johnson 2001), CF1038 daf-16(mu86)I (Lin et al. 1997), 


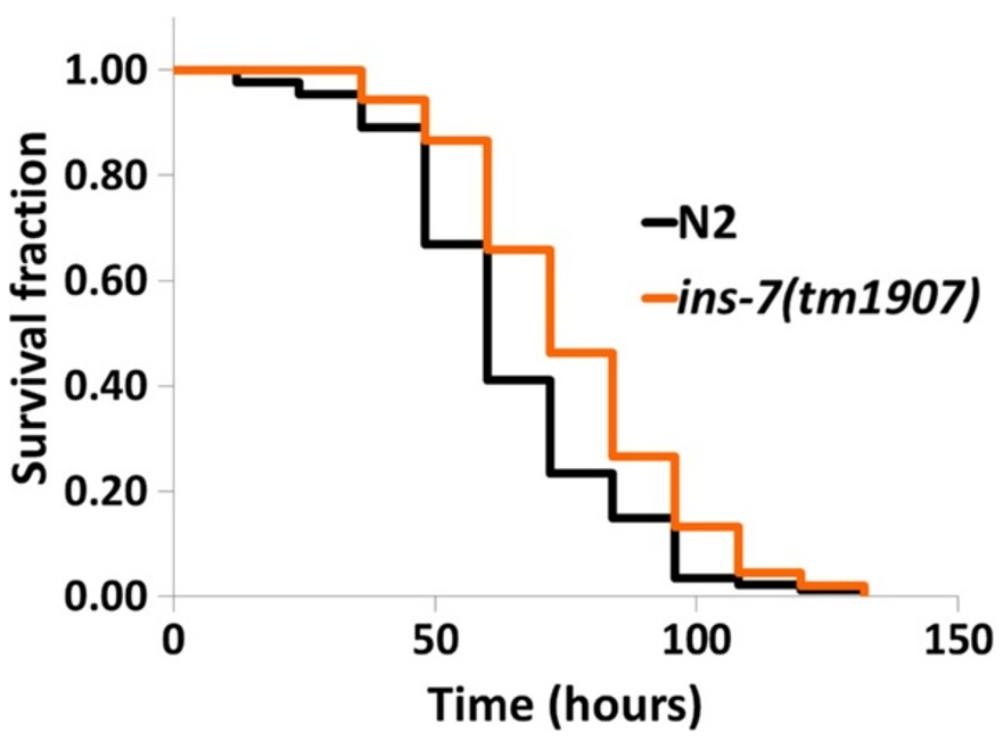

Figure 6 Deletion ins-7 mutant significantly increased lifespan. Deletion ins-7(tm 1907) mutant increased resistance against $P$. luminescens $(P<0.001)$. Survival curves are presented based on two trials (see Table 1). $P$ values were calculated by log-rank test compared with the N2.

ins-7(tm1970) (provided by the National BioResource Project, Japan), Rhabditidae sp. KHA410. Heterorhabditis bacteriophora TT01 (kindly provided by Ann Burnell, National University of Ireland-Maynooth) was maintained by infecting the greater wax moth Galleria mellonella larvae as following the methods described previously (Kaya and Stock 1997). The symbiotic bacteria P. luminescens TT01 was isolated from G. mellonella infected with $H$. bacteriophora TT01, spread on MacConkey agar plates to select the primary phase colonies. The primary phase $P$. luminescens TT01 colony was picked up, transferred into LB media and grown overnight at $28^{\circ} \mathrm{C}$ with $200 \mathrm{rpm}$ shaking. About $200 \mu \mathrm{l}$ or $400 \mu \mathrm{l}$ of the liquid cultured bacteria was spread on a $6 \mathrm{~cm}$ or $9 \mathrm{~cm}$ NGM plate, respectively, without clearance space, incubated 32 hours at $28^{\circ} \mathrm{C}$, and then cooled down to $20^{\circ} \mathrm{C}$. All fresh $P$. luminescens TT01 plates were prepared just before use.

\section{Construction of $g f p$-labeled bacteria}

GFP-labeled E. coli OP50 and P. luminescens TT01 were constructed by the miniTn7-transposon system pBKminiTn7-gfp2 and pUX-BF13 (Lambertsen et al. 2004; Easom et al. 2010). Briefly, E coli S17-1 ( $\lambda$ pir) carrying pBK-miniTn7-gfp2 (donor) and E. coli SM10 ( $\lambda$ pir) carrying pUX-BF13 (helper), and E. coli OP50 rifampicin resistance $\left(\mathrm{Rif}^{\mathrm{R}}\right)$ or P. luminescence TT01 Rif ${ }^{\mathrm{R}}$ (recipients) growing in LB medium containing $10 \mathrm{mM} \mathrm{MgCl}_{2}$ with appropriate antibiotics $(\mathrm{MgLB})\left(\mathrm{OD}_{600}=0.5\right)$ were mixed in a 1:1:4 ratio (donor: helper: recipient $=50 \mu \mathrm{l}: 50 \mu \mathrm{l}: 200 \mu \mathrm{l}$ ), dropped on the center of MgLB agar plate and then incubated overnight at $30^{\circ} \mathrm{C}$. Thereafter, bacterial cells were collected with MgLB and plated on MgLB agar containing
$50 \mu \mathrm{g} / \mathrm{ml} \mathrm{rifampicin} \mathrm{and} 5 \mu \mathrm{g} / \mathrm{ml}$ chloramphenicol, and incubated for 48 hours at $30^{\circ} \mathrm{C}$. Correct position of the $\operatorname{Tn} 7$ insertion in the colonies acquired were confirmed by PCR with the primers, Tn7-Pl_glmS, 5' - CGT AAT TTG GCT AAA TCA GTG AC - 3' and Tn7R109, 5' - CAG CAT AAC TGG ACT GAT TTC AG - 3 '.

\section{Survival test}

All survival tests were carried out at $20^{\circ} \mathrm{C}$. Synchronized L1 stage C. elegans were obtained by treating eggcontaining adults with sodium hypochlorite (Porta-dela-Riva et al. 2012) and allowed to grow on NGM plates seeded with E. coli OP50 at $20^{\circ} \mathrm{C}$ for 48 hours until the late L4 stage. L4 stage C. elegans were washed with M9 buffer and transferred onto the $6 \mathrm{~cm}$ NGM plates completely covered with $P$. luminescens TT01, and checked every 12 hours until nematode death. Preparation of the NGM plate seeded with fresh P. luminescens TT01 was described as above. The time point of nematode transfer onto the $P$. luminescens plate represented the zero hour of life-span analysis. Nematodes began to lay a few eggs after about 12 hours, but the hatched larvae couldn't grow and were easily distinguish from their parents. Nematode was considered dead when it no longer responded to light prodding with a platinum wire. Nematodes that crawled-up to the dish wall and desiccated were excluded from the data. Experiments were performed two or three times. Survival curves were analyzed by the Kaplan-Meier procedure, and significant differences between survival curves were calculated by the log-rank test with statistical software Excel Tokei 2006 (SSRI, Tokyo, Japan). 


\section{Formation of crystal-like structure}

Synchronized L4 stage C. elegans were transferred onto the $9 \mathrm{~cm}$ NGM plates completely covered with $P$. luminescens TT01, prepared as described above, and incubated at $20^{\circ} \mathrm{C}$ for 12 hours. Then nematodes were collected and washed with M9 buffer twice and transferred onto the $9 \mathrm{~cm}$ NGM plates seeded with $E$. coli OP50, and incubated at $20^{\circ} \mathrm{C}$ for 24 and 48 hours. After 24 or 48 hour incubation, 10-20 nematodes were randomly picked up and observed the formations of crystallike structure with the differential interference contrast (DIC) microscopy. Each observation was performed three times independently.

\section{RNA interference (RNAi)}

Gene fragments of C. elegans daf-2, daf-16 and pmk-1 were prepared by PCR amplification of C. elegans N2 cDNA and cloned into the RNAi vector pPD129.36 (kindly provided by Fire, A., Stanford University). The PCR fragment-ligated plasmid or the blank vector pPD129.36 was used to transform E. coli HT115 (Kamath et al. 2001). Primers for RNAi constructs were listed in Table 3. For RNAi experiments, synchronized L1 stage nematodes were cultured until L4 stage for 48 hours at $20^{\circ} \mathrm{C}$ on NGM (containing $50 \mu \mathrm{g} / \mathrm{mL}$ ampicillin and $20 \mu \mathrm{g} / \mathrm{mL}$ tetracycline) plates seeded with $E$. coli HT115 transformed with each different RNAi plasmid. Synchronized L4 stage nematodes were then collected and transferred onto survival test plates.

\section{Feeding test}

Synchronized L4 stage C. elegans were washed with M9 buffer and transferred onto the $6 \mathrm{~cm}$ NGM plates completely covered with $g f p$-tagged $P$. luminescens TT01, or $E$. coli OP50. Nematodes were picked up at every time point and observed with the Nikon E600 microscope equipped with Nomarski DIC system and a fluorescence filter.

\section{Quantitative RT-PCR}

Gene expression of spp-1, thn-2, lys-7 (reported to be controlled by the insulin/IGF-1 signaling pathway, Murphy

Table 3 Primers used for RNAi constructs 」

\begin{tabular}{|c|c|c|}
\hline & Primer name & Sequence \\
\hline 1. & $\begin{array}{l}\text { daf-16a_ } \\
\text { BamHI_For }\end{array}$ & $5^{\prime}$ - GGGGATCCGCCGGAGCCACGTGGCAGGTG - 3' \\
\hline 2. & $\begin{array}{l}\text { daf-16a_ } \\
\text { Sall_Rev }\end{array}$ & 5' - ATACGCGTCGACTCAGCTCATGTCTGATCAATG - 3' \\
\hline 3. & daf-2_Sall_For & $5^{\prime}$ - GGAGCACGATATTGTCGACGGCA - 3' \\
\hline 4. & daf-2_Xbal_Rev & $\overline{5}^{\prime}$ - GCTCTAGATTTCTGAACAGTGACTTTGCCT - 3' \\
\hline 5. & $\begin{array}{c}\text { pmk-1_- } \\
\text { EcoRI_For }\end{array}$ & $5^{\prime}$ - GGGAATTCCACAGACAACAATGGATCATAT - 3' \\
\hline 6. & $\begin{array}{l}\text { pmk-1_- } \\
\text { EcoRl_Rev }\end{array}$ & 5' - AAGGAATTCTTCATCTGGTGTTCC - 3' \\
\hline
\end{tabular}

et al. 2003; Evans et al. 2008), F08G5.6, T24B8.5, lys-2, clec-67 (reported to be controlled by the p38 MAPK pathway, Troemel et al. 2006) and ins-7 (an insulin/IGF-1 peptide and DAF-2 ligand) were analyzed by qRT-PCR using $\mathrm{SYBR}^{\circ}$ green assay (Takara bio, Shiga, Japan). Synchronized L4 stage $C$. elegans grown on the NGM seeded with E. coli OP50 were collected, washed with M9 buffer and transferred onto the $9 \mathrm{~cm}$ NGM plates completely covered with $P$. luminescens TT01 (prepared as described above) or E. coli OP50, and grown at $20^{\circ} \mathrm{C}$. After 6,12 or 24 hours, nematodes were collected, washed twice with M9 buffer, then immediately frozen in liquid nitrogen, and stored in $-80^{\circ} \mathrm{C}$ freezer. Total RNA was extracted by the RNeasy ${ }^{\circ}$ Plus Micro Kit (Qiagen, Venlo, Netherland) following the manufacturer's protocol. Total RNA (adjusted for concentration of $50 \mathrm{ng} / \mu \mathrm{l}$ ) was reverse transcribed using Oligo dT primer and PrimeScript RT reagent Kit (Takara bio). Quantitative RT-PCR was performed using SYBR $^{\circ}$ Premix Ex Taq ${ }^{\text {Th }}$ II (Tli RNaseH Plus) (Takara bio) on CFX96 ${ }^{\text {ma }}$ Real-Time PCR Detection System (Bio-Rad, Berkeley, CA, USA). Primers were designed using Primer 3 software (http://simgene.com/Primer3) and tested for specificity prior to qRT-PCR. The housekeeping snb-1 gene was used as an internal control gene for calculation of relative expression levels of each gene. Primers for qRT-PCR were listed in Table 4. A single peak at the melting temperature of the PCR-product confirmed primer specificity. Experiments were performed at least three times using independent nematode samples. Relative gene expression of each gene was analyzed using ${ }^{{ }^{\Delta}} \mathrm{CT}$ method (Livak and Schmittgen 2001).

Table 4 Primers used for qRT-PCR analysis

\begin{tabular}{|c|c|c|}
\hline & Primer name & Sequence \\
\hline 1. & F08G5.6_For & $5^{\prime}$ - ATCGTTCCGAATGGTGGTTGAC - 3' \\
\hline 2. & F08G5.6_Rev & $5^{\prime}$ - GCCGATTTCAGCTTGCAAAGTG - 3' \\
\hline 3. & T24B8.5_For & $5^{\prime}$ - AAACCTGTGGTGTCTGCGTTAC - 3' \\
\hline 4. & T24B8.5_Rev & $5^{\prime}-$ TGGCAGGTTTTGGGCATTG - 3' \\
\hline 5. & lys-2_For & $5^{\prime}$ - TGCTGATTTCCGTGCTTCG - 3' \\
\hline 6. & lys-2_Rev & $5^{\prime}-$ TTCCAACAGCATACACGTCACG - 3' \\
\hline 7. & clec-67_For & $5^{\prime}$ - AATGTTCAATCGGCCACCCTTG - 3' \\
\hline 8. & clec-67_Rev & $5^{\prime}$ - TGGTCATGTTGAAGACGTTCGC - 3' \\
\hline 9. & spp-1_For & $5^{\prime}-$ TTTGCTGGACTATGCTGTTGCC - 3' \\
\hline 10. & spp-1_Rev & $5^{\prime}-$ AACATCCTTGCACGCCTTGTC - 3' \\
\hline 11. & thn-2_For & $5^{\prime}$ - TCCAACTTACGGCTGGACAATC - 3' \\
\hline 12. & thn-2_Rev & $5^{\prime}-$ TGCATTGCTCCGAGTTTCTGC - 3' \\
\hline 13. & lys-7_For & $5^{\prime}-$ AATGTGCCGTCAAACTTGGC - 3' \\
\hline 14. & lys-7_Rev & $5^{\prime}-$ TGCACGAACGAAAACTGCAC - 3' \\
\hline 15. & ins-7_For & $5^{\prime}$ - TTAGGTCCAGCAGAACCAGAAG - 3' \\
\hline 16. & ins-7_Rev & $5^{\prime}$ - CGCATGCTITTCCACAAACCG - 3' \\
\hline 17. & snb-1_For & $5^{\prime}$ - TGGAGCGTGATCAGAAGTTGTC - 3' \\
\hline 18. & snb-1_Rev & $5^{\prime}-$ TCCACCAATACTTGCGCTTCAG - 3' \\
\hline
\end{tabular}




\section{Additional files}

\section{Additional file 1: Crystal-like structure is also constructed in} another bacteriovorous nematode. $L 4$ stage Rhabditidae sp. was cultured on $P$. luminescens for 24 hours at $25^{\circ} \mathrm{C}$. Arrow indicates crystallike structure inside the intestinal lumen.

\section{Additional file 2: Crystal-like structures do not disappear once} constructed. (A) Frequency of the crystal-like structure construction. There is no significant difference between before and after culturing on E. coli OP50 ( $P>0.05$, Fisher's exact test). Integrated data of three independent experiments are shown. (B) C. elegans body shape, grown on E. coli for 24 hours after 12-hour incubation on $P$. luminescens from the L4 stage. Scale bar, $200 \mu \mathrm{m}$. (C) Crystal-like structure in the C. elegans intestine, grown on $P$. luminescens for 12 hours from the L 4 stage. Scale bar, $50 \mu \mathrm{m}$. (D) Crystal-like structure in the C. elegans intestine, grown on E. coli for 48 hours after 12 -hour incubation on P. luminescens from the L4 stage. Arrows indicate crystal structure. Scale bar, $50 \mu \mathrm{m}$.

\section{Competing interests}

The authors declare that they have no competing interests.

\section{Authors' contribution}

Conceived and designed the experiments: KS, KH. Performed the experiments: KS, KH. Analyzed the data: KS, TY, KH. Wrote the paper: KS, TY, $\mathrm{KH}$. All authors read and approved the final manuscript.

\section{Authors' information}

JSPS Research Fellow.

\section{Acknowledgements}

Some C. elegans strains were provided by the Caenorhabditis Genetics Center (University of Minnesota, Minneapolis, MN) and Professor Shohei Mitani of the National Bioresource Project, Tokyo Women's Medical University. The plasmids, pBK-miniTn7-gfp2, pUX-BF13 were provided by Professor Søren Molin, Danmarks Tekniske Universitet. We thank to Dr. David Chi K Leung and Dr. Cláudia SL Vicente for useful comment on this manuscript. This work was supported by the Chubu University special research fund.

\section{Author details}

'Laboratory of Nematology, Department of Applied Biological Sciences, Saga University, Saga 840-8502, Japan. 'Laboratory of Terrestrial Microbial Ecology, Graduate School of Agriculture, Kyoto University, Sakyo, Kyoto 606-8502, Japan. ${ }^{3}$ The United Graduate School of Agricultural Sciences, Kagoshima University, Kagoshima 890-8580, Japan. ${ }^{4}$ Department of Environmental Biology, College of Bioscience \& Biotechnology, Chubu University, 1200 Matsumoto, Kasugai 487-8501, Japan.

Received: 25 December 2013 Accepted: 26 May 2014 Published: 1 June 2014

\section{References}

Alegado RA, Tan M-W (2008) Resistance to antimicrobial peptides contributes to persistence of Salmonella typhimurium in the C. elegans intestine. Cell Microbio 10:1259-1273, doi:10.1111/j.1462-5822.2008.01124.x

Bintrim SB, Ensign JC (1998) Insertional inactivation of genes encoding the crystalline inclusion proteins of Photorhabdus luminescens results in mutants with pleiotropic phenotypes. J Bacteriol 180:1261-1269

Bowen D, Rocheleau TA, Blackburn M, Andreev O, Golubeva E, Bhartia R, ffrenchConstant RH (1998) Insecticidal toxins from the bacterium Photorhabdus luminescens. Science 280:2129-2132, doi:10.1126/science.280.5372.2129

Brenner S (1974) The genetics of the nematode Caenorhabditis elegans. Genetics $77: 71-94$

Ciche T (2007) The biology and genome of Heterorhabditis bacteriophora. WormBook, doi:10.1895/wormbook.1.135.1

Ciche TA, Ensign J (2003) For the insect pathogen Photorhabdus luminescens, which end of a nematode is out? Appl Environ Microbiol 69:1890, doi:10.1128/AEM.69.4.1890-1897.2003

Couillault C, Ewbank JJ (2002) Diverse bacteria are pathogens of Caenorhabditis elegans. Infect Immun 70:4705-4707, doi:10.1128/IAI.70.8.4705-4707.2002
Daborn PJ, Waterfield N, Silva CP, Au CPY, Sharma S, ffrench-Constant RH (2002) A single Photorhabdus gene, makes caterpillars floppy ( $m c f)$, allows Escherichia coli to persist within and kill insects. Proc Natl Acad Sci U S A 99:10742-10747, doi:10.1073/pnas.102068099

Dowling AJ, Daborn PJ, Waterfield NR, Wang P, Streuli CH, ffrench-Constant RH (2004) The insecticidal toxin Makes caterpillars floppy (Mcf) promotes apoptosis in mammalian cells. Cell Microbiol 6:345-353, doi:10.1046/j.14625822.2003.00357.x

Dowling AJ, Waterfield NR, Hares MC, Goff GL, Streuli CH, ffrench-Constant RH (2007) The Mcf1 toxin induces apotosis via the mitochondrial pathway and apoptosis is attenuated by mutation of $\mathrm{BH} 3$-like domain. Cell Microbiol 9:2470-2484, doi:10.1111/j.1462-5822.2007.00974.x

Duchaud E, Rusniok C, Frangeul L, Buchrieser C, Givaudan A, Taourit S, Bocs S, Boursaux-Eude C, Chandler M, Charles J-F, Dassa E, Derose R, Derzelle S, Freyssinet G, Gaudriault S, Médigue C, Lanois A, Powell K, Siguier P, Vincent R, Wingate V, Zouine M, Glaser P, Boemare N, Danchin A, Kunst F (2003) The genome sequence of the entomopathogenic bacterium Photorhabdus luminescens. Nat Biotechnol 21:1307-1313, doi:10.1038/nbt886

Easom CA, Joyce SA, Clarke DJ (2010) Identification of genes involved in the mutualistic colonization of the nematode Heterorhabditis bacteriophora by the bacterium Photorhabdus luminescens. BMC Microbiol 10:45, doi:10.1186/ 1471-2180-10-45

Eleftherianos I, Boundy S, Joyce SA, Aslam S, Marshall JW, Cox RJ, Simpson TJ, Clarke DJ, ffrench-Constant RH, Reynolds SE (2007) An antibiotic produced by an insect-pathogenic bacterium suppresses host defenses through phenoloxidase inhibition. Proc Natl Acad Sci U S A 92:7764-7768, doi:10.1073/pnas.0610525104

Engelmann I, Griffon A, Tichit L, Montañana-Sanchis F, Wang G, Reinke V Waterston RH, Hillier LW, Ewbank JJ (2011) A comprehensive analysis of gene expression changes provoked by bacterial and fungal infection in C. elegans. PLOS One 6:e19055

Evans EA, Kawli T, Tan M-W (2008) Pseudomonas aeruginosa suppresses host immunity by activating the DAF-2 Insulin-Like Signaling Pathway in Caenorhabditis elegans. PLoS Pathog 4:e1000175, doi:10.1371/journal.ppat.1000175

ffrench-Constant RH, Dowling A, Waterfield NR (2007) Insecticidal toxins from Photorhabdus bacteria and their potential use in agriculture. Toxicon 49:436-451, doi:10.1016/j.toxicon.2006.11.019

Fischer M, Regitz C, Kahl M, Werthebach M, Boll M, Wenzel U (2012) Phytoestrogens genistein and daidzein affect immunity in the nematode Caenorhabditis elegans via alterations of vitellogenin expression. Mol Nutr Food Res 56:957-965, doi:10.1002/mnfr.201200006

Fischer M, Regitz C, Kull R, Boll M, Wenzel U (2013) Vitellogenins increase stress resistance of Caenorhabditis elegans after Photorhabdus luminescens infection depending on the steroid-signaling pathway. Microb InfeCt 15:569-578, doi:10.1016/j.micinf.2013.05.002

Garsin DA, Sifri CD, Mylonakis E, Qin X, Singh KV, Murray BE, Calderwood SB Ausubel FM (2001) A simple model host for identifying Gram-positive virulence factors. Proc Natl Acad Sci U S A 98:10892-10897, doi:10.1073/ pnas. 191378698

Garsin DA, Villanueva JM, Begun J, Kim DH, Sifri CD, Calderwood SB, Ruvkun G, Ausubel FM (2003) Long-lived C. elegans daf-2 mutants are resistant to bacterial pathogens. Science 300:1921, doi:10.1126/science.1080147

Gatsogiannis C, Lang AE, Meusch D, Pfaumann V, Hofnagel O, Benz R, Aktories K, Raunser S (2013) A syringe-like injection mechanism in Photorhabdus luminescens toxins. Nature 495:520-523, doi:10.1038/nature11987

Gulcu B, Hazir S, Kaya HK (2012) Scavenger deterrent factor (SDF) from symbiotic bacteria of entomopathogenic nematodes. J Invertebr Pathol 110:326-333, doi:10.1016/j.jip.2012.03.014

Henderson ST, Johnson TE (2001) daf-16 integrates developmental and environmental inputs to mediate aging in the nematode Caenorhabditis elegans. Curr Biol 11:1975-1980, doi:10.1016/S0960-9822(01)00594-2

Julien-Gau I, Schmidt M, Kurz CL (2014) f57f4.4p:.:gfp as a fluorescent reporter for analysis of the C. elegans response to bacterial infection. Dev Comp Immunol 42:132-137, doi:10.1016/j.dci.2013.08.024

Kamath RS, Martinez-Campos M, Zipperlen P, Fraser AG, Ahringer J (2001) Effectiveness of specific RNA-mediated interference through ingested double-stranded RNA in Caenorhabditis elegans. Genome Biol 2:research0002.1-research0002.10, doi:10.1186/gb-2000-2-1-research0002

Kawli T, Tan M-W (2008) Neuroendocrine signals modulate the innate immunity of Caenorhabditis elegans through insulin signaling. Nat Immunol 9:1415-1424, doi:10.1038/ni.1672 
Kaya HK, Stock SP (1997) Techniques in insect nematology. In: Lacey LA (ed) Manual of Techniques in Insect Pathology. Academic Press, San Diego, pp 281-324

Kim DH, Feinbaum R, Alloing G, Emerson FE, Garsin DA, Inoue H, Tanaka-Hino M, Hisamoto N, Matsumoto K, Tan M-W, Ausubel FM (2002) A conserved p38 MAP kinase pathway in Caenorhabditis elegans innate immunity. Science 297:623-626, doi:10.1126/science.1073759

Kurz CL, Chauvet S, Andrès E, Aurouze M, Vallet I, Michel GP, Uh M, Celli J, Filloux A, De Bentzmann S, Steinmetz I, Hoffmann JA, Finlay BB, Gorvel JP, Ferrandon D, Ewbank JJ (2003) Virulence factors of the human opportunistic pathogen Serratia marcescens identified by in vivo screening. EMBO J 22:1451-1460, doi:10.1093/emboj/cdg159

Lambertsen L, Sternberg C, Molin S (2004) Mini-Tn7 transposons for site-specific tagging of bacteria with fluorescent proteins. Environ Microbiol 6:726-732, doi:10.1111/j.1462-2920.2004.00605.x

Lang AE, Schmidt G, Schlosser A, Hey TD, Larrinua IM, Sheets JJ, Mannherz HG, Aktories K (2010) Photorhabdus luminescens toxins ADP-ribosylate actin and RhoA to force actin clustering. Science 327:1139-1142, doi:10.1126/ science.1184557

Lang AE, Schmidt G, Sheets JJ, Aktories K (2011) Targeting of the actin cytoskeleton by insecticidal toxins from Photorhabdus luminescens. N Schmied Arch Pharmacol 383:227-235, doi:10.1007/s00210-010-0579-5

Lang AE, Konukiewitz J, Aktories K, Benz R (2013) TcdA1 of Photorhabdus luminescens: electrophysiological analysis of pore formation and effector binding. Biophys J 105:376-384, doi:10.1016/j.bpj.2013.06.003

Lin K, Dorman JB, Rodan A, Kenyon C (1997) daf-16: An HNF-3/forkhead family member that can function to double the life-span of Caenorhabditis elegans. Science 278:1319-1322, doi:10.1126/science.278.5341.1319

Livak KJ, Schmittgen TD (2001) Analysis of relative gene expression data using real-time quantitative PCR and the $2^{-\Delta \Delta C T}$ method. Methods 25:402-440, doi:10.1006/meth.2001.1262

Murphy CT, McCaroll SA, Bargmann Cl, Fraser A, Kamath RS, Ahringer J, Li H, Kenyon C (2003) Genes that act downstream of DAF-16 to influence the lifespan of Caenorhabditis elegans. Nature 424:277-284, doi:10.1038/nature01789

Noguez JH, Conner ES, Zhou Y, Ciche TA, Ragains R, Butcher RA (2012) A novel ascaroside controls the parasitic life cycle of the entomopathogenic nematode Heterorhabditis bacteriophora. ACS Chem Biol 7:961-966, doi:10.1021/cb300056q

Papp D, Csermely P, Sőti C (2012) A role for SKN-1/Nrf in pathogen resistance and immunosenescence in Caenorhabditis elegans. PLoS Pathog 8:e1002673, doi:10.1371/journal.ppat.1002673

Porta-de-la-Riva M, Fontrodona L, Villanueva A, Cerón J (2012) Basic Caenorhabditis elegans Methods: Synchronization and Observation. J Vis Exp 64:e4019, doi:10.3791/4019

Pujol N, Link EM, Liu LX, Kurz CL, Alloing G, Tan M-W, Ray KP, Solari R, Johnson CD, Ewbank JJ (2001) A reverse genetic analysis of components of the Toll signaling pathway in Caenorhabditis elegans. Curr Biol 11:809-821, doi:10.1016/S0960-9822(01)00241-x

Richardson WH, Schmidt TM, Nealson KH (1988) Identification of an anthraquinone pigment and a hydroxystilbene antibiotic from Xenorhabdus /uminescens. Appl Environ Microbiol 54:1602-1605, doi:0099-2240/88/061602-04

Shivers RP, Kooistra T, Chu SW, Pagano DJ, Kim DH (2009) Tissue-specific activities of an immune signaling module regulate physiological responses to pathogenic and nutritional bacteria in C. elegans. Cell Host Microbe 6:321-330, doi:10.1016/j.chom.2009.09.001

Shivers RP, Pagano DJ, Kooistra T, Richardson CE, Reddy KC, Whitney JK, Kamanzi O, Matsumoto K, Hisamoto N, Kim DH (2010) Phosphorylation of the conserved transcription factor ATF-7 by PMK-1 p38 MAPK regulates innate immunity in Caenorhabditis elegans. PLOS Genet 6:e1000892, doi:10.1371/journal. pgen.1000892

Sicard M, Hering S, Schulte R, Gaudriault S, Schulenburg H (2007) The effect of Photorhabdus luminescens (Enterobacteriaceae) on the survival, development, reproduction and behaviour of Caenorhabditis elegans (Nematoda: Rhabditidae). Environ Microbiol 9:12-25, doi:10.1111/j.1462-2920.2006.01099.x

Spanier B, Starke M, Higel F, Scherer S, Fuchs TM (2010) Yersinia enterocolitica infection and tcaA-dependent killing of Caenorhabditis elegans. Appl Environ Microbiol 76:6277-6285, doi:10.1128/AEM.01274-10

Tan M-W, Shapira M (2011) Genetic and molecular analysis of nematode-microbe interactions. Cell Microbiol 13:497-507, doi:10.1111/j.1462-5822.2011.01570.x

Tan M-W, Mahajan-Miklos S, Ausubel FM (1999) Killing of Caenorhabditis elegans by Pseudomonas aeruginosa used to model mammalian bacterial pathogenesis. Proc Natl Acad Sci U S A 96:715-720, doi:10.1073/pnas.96.2.715
Tenor JL, Aballay A (2008) A conserved Toll-like receptor is required for Caenorhabditis elegans innate immunity. EMBO Rep 9:103-109, doi:10.1038/sj.embor.7401104

Troemel ER, Chu SW, Reinke V, Lee SS, Ausubel FM, Kim DH (2006) p38 MAPK regulates expression of immune response genes and contributes to longevity in C. elegans. PLoS Genet 2:e183

van der Hoeven R, McCallum KC, Cruz MR, Garsin DA (2011) Ce-Duox1/BLI-3 generated reactive oxygen species trigger protective SKN-1 activity via $\mathrm{p} 38$ MAPK signaling during infection in C. elegans. PLoS Pathog 7:e1002453

Visschedyk DD, Perieteanu AA, Turgeon ZJ, Fieldhouse RJ, Dawson JF, Merrill AR (2010) Photox, a novel actin-targeting mono-ADP-ribosyltransferase from Photorhabdus luminescens. J Biol Chem 285:13525-13534, doi:10.1074/jbc. M109.077339

Vlisidou I, Dowling AJ, Evans IR, Waterfield N, ffrench-Constant RH, Wood W (2009) Drosophila embryos as model systems for monitoring bacterial infection in real time. PLoS Pathog 5:e1000518, doi:10.1371/journal.ppat.1000518

Waterfield NR, Sanchez-Contreras M, Eleftherianos I, Dowling A, Yang G, Wilkinson P, Parkhill J, Thomson N, Reynolds SE, Bode HB, Dorus S, ffrench-Constant RH (2008) Rapid Virulence Annotation (RVA): identification of virulence factors using a bacterial genome library and multiple invertebrate hosts. Proc Natl Acad Sci U S A 105:15967-15972, doi:10.1073/pnas.0711114105

Waterfield NR, Ciche T, Clarke D (2009) Photorhabdus and a host of hosts. Annu Rev Microbiol 63:557-574, doi:10.1146/annurev.micro.091208.073507

Williams JS, Thomas M, Clarke DJ (2005) The gene st/A encodes a phenylalanine ammonia-lyase that is involved in the production of a stilbene antibiotic in Photorhabdus luminescens TT01. Microbiology 151:2543-2550, doi:10.1099/ mic.0.28136-0

Yang G, Waterfield NR (2013) The Role of TcdB and TccC Subunits in Secretion of the Photorhabdus Tcd Toxin Complex. PLoS Pathog 9:e1003644, doi:10.1371/ journal.ppat.1003644

doi:10.1186/2193-1801-3-274

Cite this article as: Sato et al:: Activated and inactivated immune responses in Caenorhabditis elegans against Photorhabdus luminescens TT01. SpringerPlus 2014 3:274.

\section{Submit your manuscript to a SpringerOpen ${ }^{\circ}$ journal and benefit from:}

- Convenient online submission

Rigorous peer review

- Immediate publication on acceptance

- Open access: articles freely available online

- High visibility within the field

- Retaining the copyright to your article

Submit your next manuscript at $>$ springeropen.com 